\title{
THE EFFECTS OF TOURISM ON VERNACULAR HOUSES IN TRADITIONAL VILLAGE: THE COMPARISON BETWEEN KAMPUNG NAGA IN WEST JAVA AND DESA KANEKES IN BANTEN
}

\author{
Muhammar Khamdevi \\ Association of Indonesian Professionals for Science, Technology and Enterprises (AIPSE) \\ Arch fiqh@yahoo.com
}

\begin{abstract}
Tourism is one of the significant economic sectors in Indonesia. It has major, economic, social and environmental impacts. However, it may become unsustainable tourism, if its management ignores environmental issues, especially the degradation of the cultural heritage environment. Kampung Naga in West Java and Desa Kanekes in Banten are two cultural heritage villages that became tourist attractions in Indonesia. Their vernacular houses experienced several shifts and changes since then. How are the effects of tourism in Kampung Naga and Desa Kanekes on their vernacular houses? Are there any differences between both of them? A comparative approach is adopted in investigating the cases. This study is expected to find the implementation of current tourism in both villages and its effects on vernacular houses. The study shows that unsustainable tourism is occurred in both locations and result several concerned effects on their vernacular houses.
\end{abstract}

Keywords: sustainable tourism, cultural heritage, vernacular architecture

ABSTRAK. Pariwisata adalah salah satu sektor ekonomi penting di Indonesia. la memiliki dampak ekonomi, sosial dan lingkungan. Meskipun begitu, ia menjadi pariwisata tidak berkelanjutan, jika pengelolaannya mengabaikan isu-isu lingkungan, terutama penurunan kualitas lingkungan warisan budaya. Kampung Naga di Jawa Barat dan Desa Kanekes di Banten adalah dua kampung warisan budaya yang menjadi tujuan wisata di Indonesia. Rumah-rumah vernakularnya mengalami pergeseran dan perubahan sejak saat itu. Bagaimana pengaruh pariwisata di Kampung Naga dan Desa Kanekes pada rumah-rumah vernakularnya? Apakah ada perbedaan di antara keduanya? Pendekatan komparatif dipakai untuk menyelidiki kasus tersebut. Kajian ini diharapkan untuk menemukan pelaksanaan pariwisata saat ini di kedua kampung dan pengaruhnya pada rumah-rumah vernakularnya. Hasil kajian menunjukkan bahwa pariwisata yang tidak berkelanjutan terjadi di kedua lokasi dan menghasilkan beberapa pengaruh-pengaruh yang memprihatinkan pada rumah-rumah vernakularnya.

Kata Kunci: pariwisata berkelanjutan, warisan budaya, arsitektur vernakular

\section{INTRODUCTION}

Modernization gives a great impact on the world, especially Indonesia. Globalization has a part the process acceleration to transmit western values [1]. As a result, the new phenomenon has emerged, called cultural imperialism [2]. Colonized local communities usually imitate the colonizers in facing colonial values [3]. Unconsciously, they leave their cultural values and identity, and tend to accept western culture as the only value of modern civilization. It is one of the characteristics of consumer behaviour that is affected by the culture of global capitalism. The result is a cultural transition that moves from local values to the global values [4].

This process also often urbanized many villages in Indonesia, except cultural heritage villages that still strictly maintains its local wisdom, like Kampung Naga in West Java and Desa Kanekes in Banten. Local wisdom leads human behavior in life in ecological communities, such as knowledge, belief, understanding, or insight as well as custom or ethic [5].

However, since many cultural villages opened to public as tourist attractions to stimulate their economic incomes, the wave of modernization seemed unstoppable. This mass tourism became a staging tourism, where people and their culture are just a public display of bodies - how they look, what they do, where they do it, who watches, and under what conditions [6]. The mass tourism has tended to be a living museum of art and culture that promises the glamorous life of the local community [7]. By reason of tourist visits in large numbers, it is possible that the local communities affected by the modern lifestyle of the tourists, which could also affected how they treat their vernacular houses.

Theoretically, mass tourism is supposed to give great contributions to the communities. In reality, it gives negative impacts in economic, 
social, cultural, and environmental life of local community [8]. Despite holding a strong values, there should be at least some adjustments and changes that had to be done, especially on their vernacular houses when they have lack of financial and material resources.

These issues of mass tourism has produced a paradigm shift in tourism development; mass tourism model to alternative tourism (or sustainable tourism) models [9]. Finding a new method, which is a more appropriate and sustainable, is important. Where tourists should be involved in the daily activities of the communities and contribute to preserve cultural heritage villages. This study is trying to evaluate the implementation of current tourism in Kampung Naga and Desa Kanekes. Then both cases will be compared, to give a comperehensive description and to discover the strengths and weaknesses of both as a lesson learned in the future.

\section{METHODS}

In investigating the cases, a comparative method is used. This approach intends to unsderstand one independent variable by comparing two or more samples. In this case, the variable is the effects of tourism on vernacular houses and the samples are Kampung Naga and Desa Kanekes (outer village and inner village). Then two samples will be analyzed to get similarities and differences, the possibility of causal relationship, and determination which one is better or which one should be selected.

The data is obtained from qualitative resources, such as the interview manuscripts, field notes, photographs and others in the form of words, pictures, and figures. All data then is described to get an overview of the phenomenon in the field. Then the phenomenon will be analyzed to draw a conclusion [10].

\section{RESULT AND DISCUSSION}

\section{Kampung Naga, West Java}

Kampung Naga is located between Tasikmalaya and Garut in Salawu District, Tasikmalaya Regency, West Java Province. There are currently 109 family who inhabit \pm 1.5 acres total area [11]. Kampung Naga is established as a cultural tourism area since 2005. In 2010 tourist growth went up to $443.4 \%$ and the tourist numbers are reaching 45,373 peoples, and in 2011 rose to $29.6 \%$ and the tourists numbers are reaching 58,811 peoples. In recent research shows that the number of visits exceeded its carrying capacity, so that the local community feel more uncomfortable. Its maximum number of visitors is 255 people / day, while its minimum number of visitors is 95 people / day (Kusnandar et.al., [12].

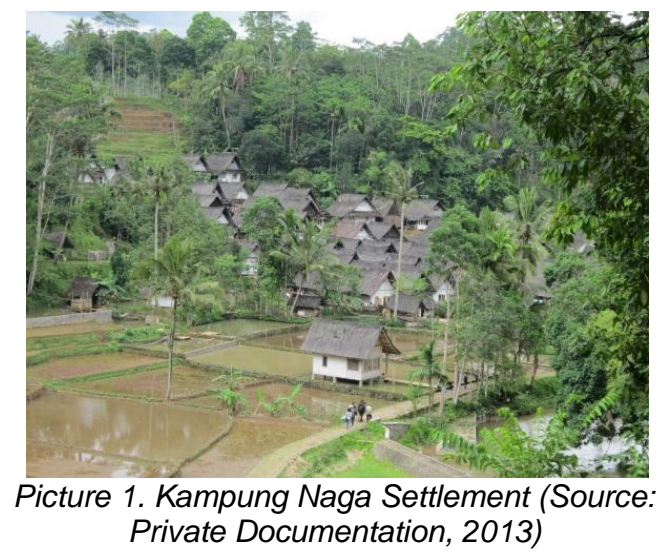

The community of Kampung Naga has run their own 'customary law', especially in building their houses. There are several procedures that should be obeyed. The house should be a stilt house with basic materials from woods for poles (tihang), doors (panto), windows (jandela) and bamboos foe walls (bilik). The roof covering (hanteup) are made of palm fiber (ijuk) roofed with palm leaf (rumbia) as the base [13]. The houses are lined up from east to west with the front of the house facing the south or north. The house is symbolized the relationship between the natural world and the inner world [11]. In one reserach shows that the houses in Kampung Naga are sustainable. The energy consumption and occupancy are highly efficient and environment friendly [14].

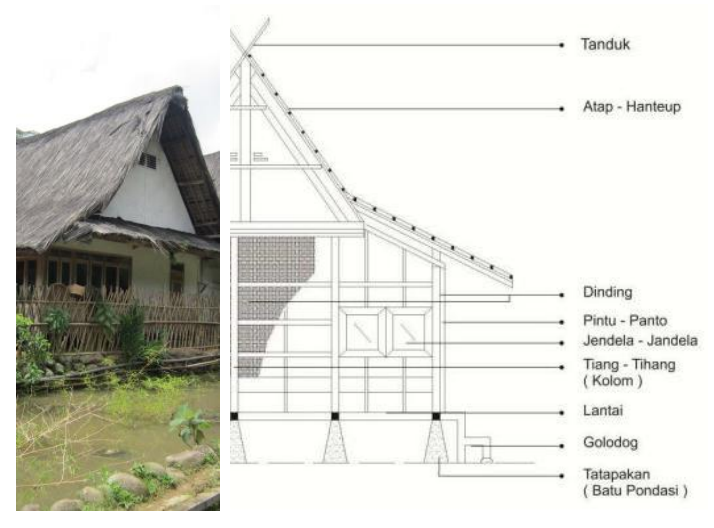

Picture 2. The Vernacular House in Kampung Naga (Source: Private Documentation, 2013 and Utami et al., 2014) 
Parking area is located outside the village. It is managed by local governments with parking fee Rp. 7,000 / car, which is expensive. While the tour guides are the local villagers who tend to be paid low. Imagine, how much money goes into the regional government and how much goes into the local community. Of course, there are souvenir shops that is located close to parking area. But all traders is not locals. Only a few kiosks are inside the village that sell souvenirs, that is attached to the front side of the house near the little veranda (golodog).

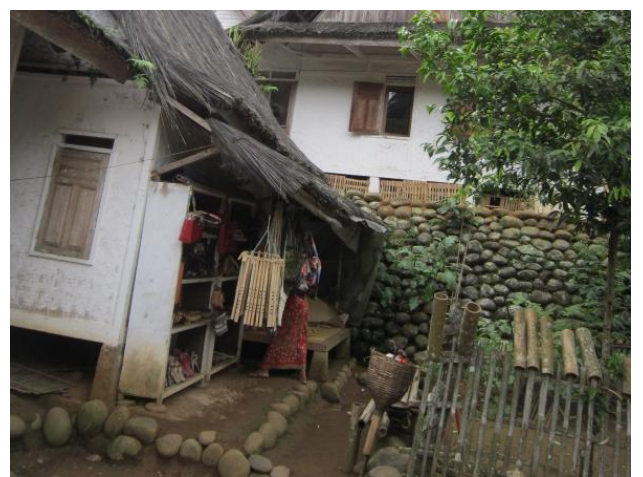

Picture 3. The Little Kiosk Attached on The Front Side of The House (Source: Private Documentation, 2013)

The activities that the tourist do most are sightseeing, taking pictures and buying souvenirs. These activities are a phenomenon in tourism that is what Desmond describes as staging tourism or Suryawan describe as a living museum of art and culture. Actually we can also stay in the village by renting a living room (tepas imah) of the house owner, but this is only for the students, academics or researchers and only in the allowed days, because there are forbidden days in Kampung Naga to talk about history or stories about ancestors, like Tuesday, Wednesday, and Saturday. Moreover there is no accommodation that is close to the village.

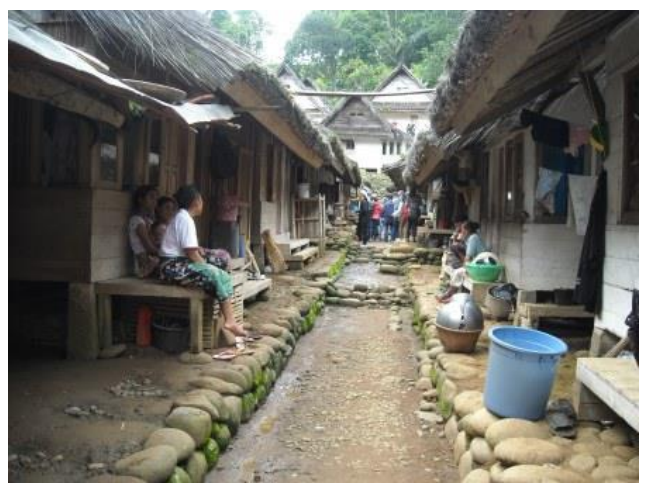

Picture 4. The (Staging) Tourism in Kampung Naga (Source: Private Documentation, 2013)

Sadly, the current tourism could not give good impact on the economy of local community. Because of the lack of financial resources, the architecture of vernacular houses in Kampung Naga are shifted, especially in the use of common materials comercially, which are cheaper and easily available in materials store than formerly materials, but do not violate the tradition of not using non-natural materials. Furthermore there is also other factor, which is the diminishing of forest outside the village area that usually produce raw materials for building the house [15]. Actually, Kampung Naga has forests; the sacred forest is located in the west side of the village which is ancestral graves and the forbidden forest is in the east which is the source of the local community livelihood, but only a small part that could be used.

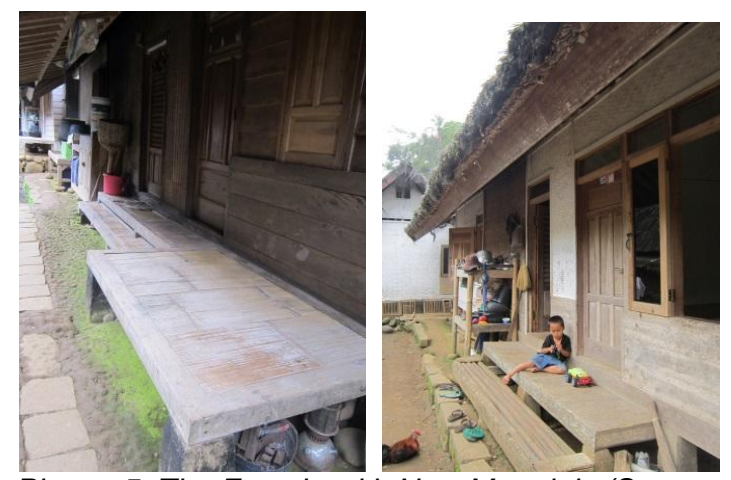

Picture 5. The Facade with New Materials (Source: Private Documentation, 2013)

The local community in Kampung Naga actually has knowledge to build the house, like most in Indonesian indigenous culture. People work together to find wood in the forest and process it. But now, materials are purchased. In the future this culture would be lost and the knowledge would be disconnected. [16].
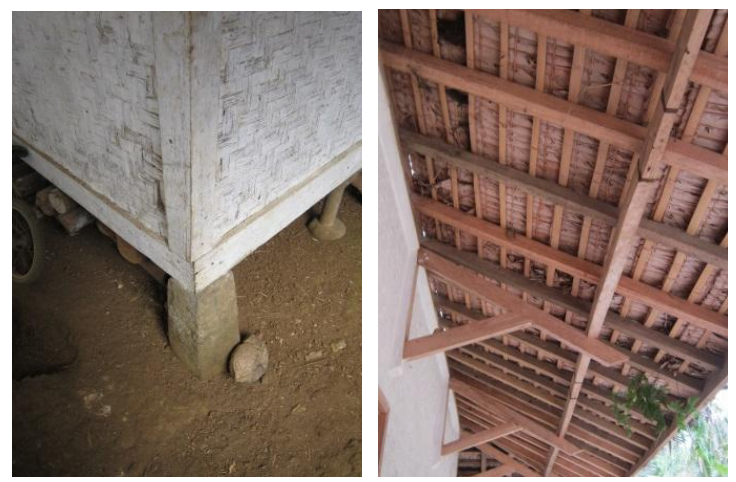

Picture 6. The New Materials (Source: Private Documentation, 2013) 
So, they starts to use wood panels for walls and doors as a substitute for bamboos and glass panels for windows as a substitute for jalousie windows. They also now use nails, instead of using stake as they use before. In one study shows the number of changes that apply in the vernacular houses, for instance; the addition of front door for guests or relatives to stay, the subtitution of pedestal foundation from a solid rock to chiseled stone, the subtitution of bamboo rafters into the wood rafters, the subtitution of bamboo flooring into wood flooring [17]. These changes have been permitted by customary leaders.

\section{Desa Kanekes, Banten}

Desa Kanekes (or Kampung Baduny) is located in Lebak-Rangkas Bitung Regency, about $40 \mathrm{~km}$ from Rangkasbitung City. The size of Desa Kanekes is 5.108 hectares. Desa Kanekes consist of two regions; Tangtu / Inner Kanekes Villages (Cibeo, Cikartawana) and Panamping / Outer Kanekes Villages (Cikadu, Kadutek, Kadukolot, Gajeboh, Cisagu, etc.). The community in inner Desa Kanekes have a strong tradition rather than the community in outer Desa Kanekes. The community in outer Desa Kanekes are those who came out from the custom and region of inner Desa Kanekes. They have known the culture outside the region of Desa Kanekes [18].

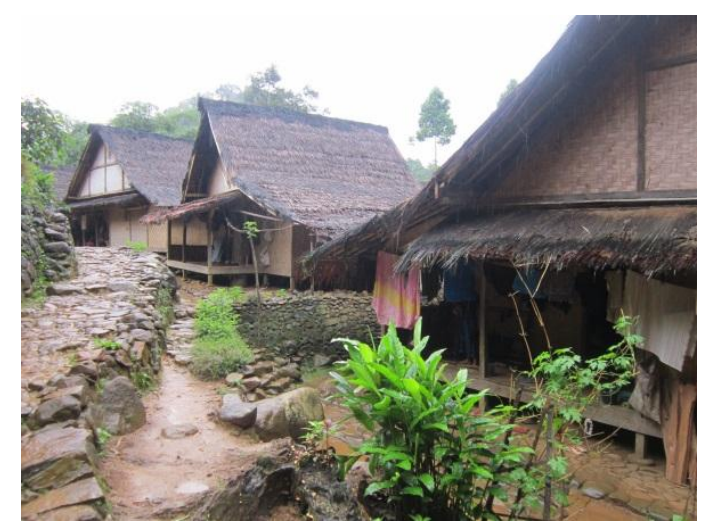

Picture 7. Desa Kanekes Settlement - Outer Village (Source: Private Documentation, 2014)

Since 1992, the government of Lebak Regency has established Desa Kanekes as a tourist attraction. The opening was also followed by the bus terminal construction in Ciboleger. The number of visits to the village of Kanekes reached 15,000 per year. The tourism management initially handled by the government of Lebak Regency, but since 2006 the management was handed over to indigenous leaders of Desa Kanekes.

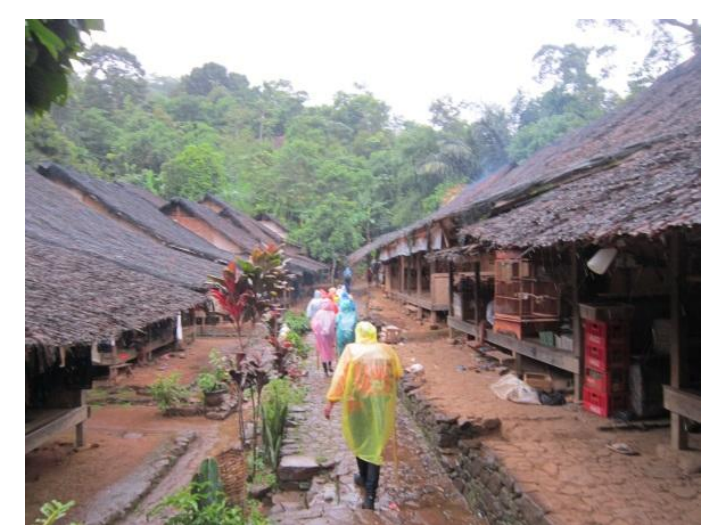

Picture 8. The (Staging) Tourism in Desa Kanekes Outer Village (Source: Private Documentation, 2014)

However, the community of Desa Kanekes felt treated like "animals show". The common activities that the tourist do most are making research (student or researcher), sightseeing, taking pictures and buying souvenirs. The tourists also often interfere the traditional life of the local community. They also disturbed, especially if the tourists are coming to make noise or customs offenses. And they are worried, that the tourists affected the behavior of the community. Actually, the community will not forbid if the "outsiders" visit their village. But only for such purposes; pilgrimages or doing research.

However, it can not be denied that the tourism had a positive impact on the economy of the community. They can sell their woven fabric to the tourists. And sometimes people of Desa Kanekes also got a rent money from the guests who stay in their house [19].

There are some rules, when tourist wants to visit Desa Kanekes. The tourist should obey and respect the custom law of Desa Kanekes. They should not bring any electronic devices, music instruments, weaponry, they should not hunt and kill animals, they should not litter any waste, etc. Foreigners are banned from entering the region of inner Kanekes. Using camera inner Kanekes territory is prohibited. In February and April inner Kanekes is closed to outsiders [20]. 


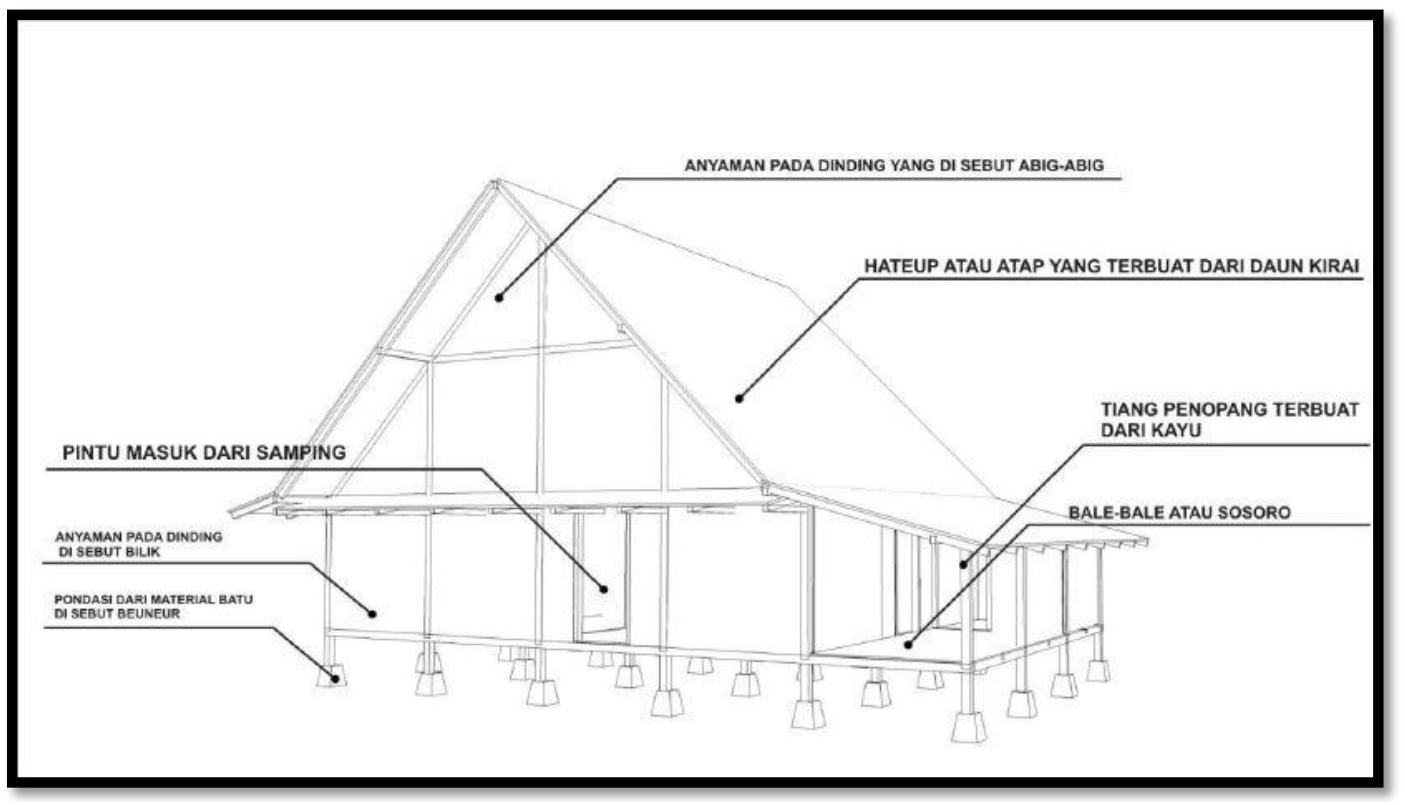

Picture 9. The Vernacular Houses in Desa Kanekes - Outer Village (Source: Jamaludin et al., 2013)

Generally, the community of Desa Kanekes divided their area into three zones; lower zone for settlments, middle zone for production (agriculture), upper zone for forest conservation (leuweung kolot / titipan) [21]. The form of the vernacular house is a stilt house with simple shape and has symbolic meaning. The front of the house facing the south or north. The materials is derived from the nature around them, such as wood for poles, bamboo for the walls (giribig or bilik), doors, windows, flooring (palupuh) and roof structure (usuk and reng), solid rocks for foundation (tatapakan) and palm leaves (kiray/ rumbia) for the roof [22].

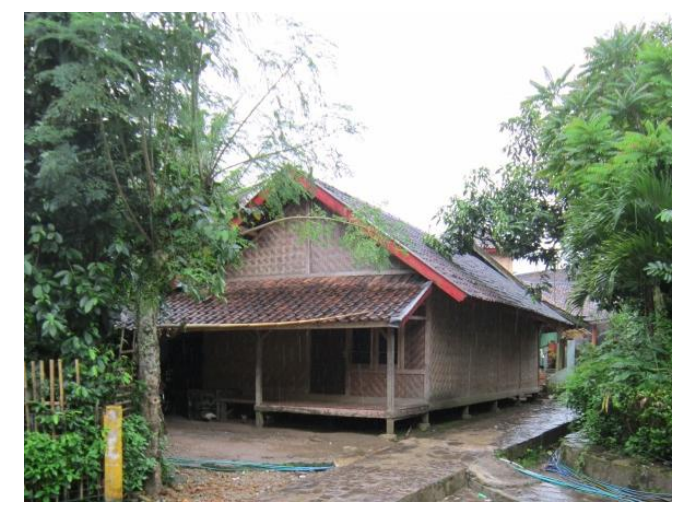

Picture 10. The Facade with New Materials - Outer Village (Source: Private Documentation, 2014)

The community of inner Kanekes still maintained the originality of their houses. They still use the same procedures, methods and materials. But in outer Kanekes, some people have used new materials, such as, wood (for doors, windows and walls), nails, roof tile etc., because the materials are easily available and cheaper at the nearby material store. These changes have been permitted by customary leaders.

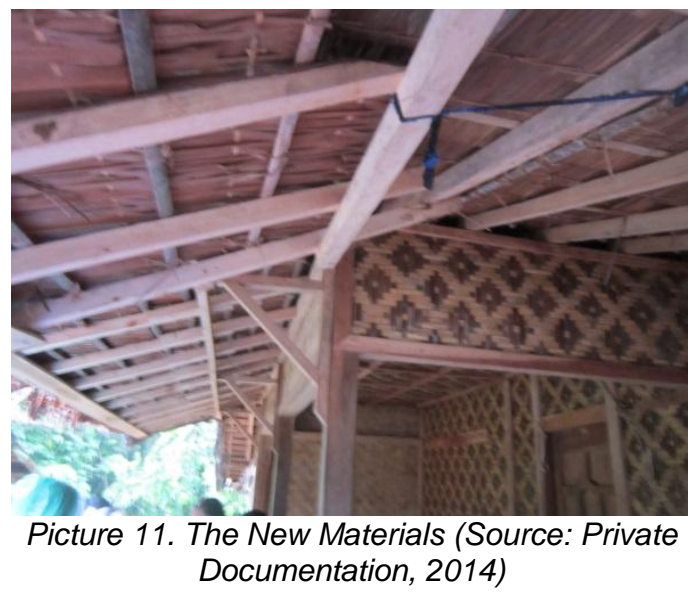

Some people of outer Kanekes have also used their veranda (sosoro) for economic activities to sell souvenirs or some used a little of the living room (imah) to sell food, daily needs and drinks (warung) and veranda as dining space for customers. In inner and outer Kanekes, the house owner can rent their living room space as for guest or tourist to stay. 


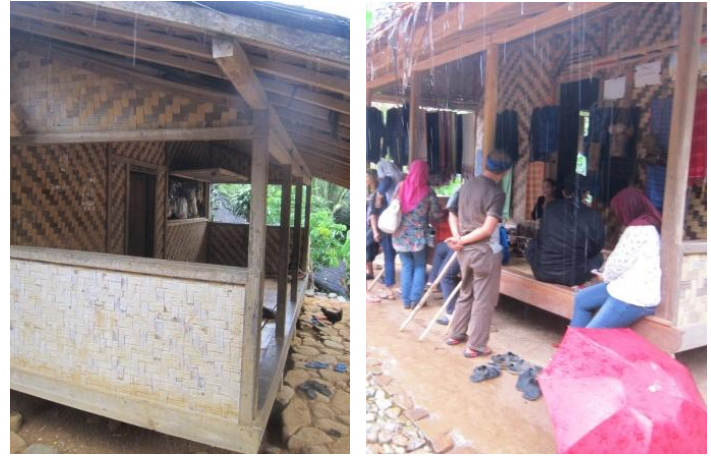

Picture 12. The Kiosk on The Veranda of The House (Source: Private Documentation, 2014)

\section{CONCLUSION}

From the discussion, mass tourism indeed give effects on the vernacular houses in Kampung Naga and Desa Kanekes. Most problems are because of the availability of local materials and the ability to buy the materials in the same quality from nearby material store. Because the local materials are limited and expensive, they replaced them with cheaper materials. On the other hand, some local people also affected by the modern culture outside the village or that the tourist brought. There is no doubt that some villagers have a culture transition from traditional to modern (west). It can be seen from the use of glass in a window, the use of contemporary style at the door and also the use of hinges.

However, there are no major changes in spatial layout and symbolic values of the house. Only commercial function added in the house by using existing space (a whole or only partially), such as; kiosk by using veranda to sell souvenir, kiosk by using living room to sell daily needs and snacks, and homestay by using living room for guests and tourists to stay.

In the future, making a better tourism program is a must to save our vernacular buildings. The activities should not passive but also active, which tourists involves in any recreational and educational activities, culturally and ecologically, in maintaining biodiversity and cultural structures, as well as helping the local economy and promoting the development of Village Tourism. This kind of tourism is called as sustainable tourism. This tourism could provide a more interactive experiences.
Diagram 1. The Effect of Tourism on The Vernacular Houses

\begin{tabular}{|c|c|c|c|}
\hline $\begin{array}{l}\text { Architectural } \\
\text { Elements }\end{array}$ & $\begin{array}{c}\text { Kampung } \\
\text { Naga }\end{array}$ & $\begin{array}{c}\text { Outer } \\
\text { Kanekes }\end{array}$ & $\begin{array}{c}\text { Inner } \\
\text { Kanekes }\end{array}$ \\
\hline $\begin{array}{l}\text { Symbolic } \\
\text { Meaning }\end{array}$ & & - & - \\
\hline $\begin{array}{l}\text { Spatial Layout } \\
\text { and Function }\end{array}$ & $\begin{array}{c}\mathrm{v} \\
\text { kiosk in } \\
\text { veranda } \\
\text { homestay } \\
\text { in living } \\
\text { room }\end{array}$ & $\begin{array}{c}\mathrm{v} \\
\text { kiosk in } \\
\text { veranda } \\
\text { and living } \\
\text { room } \\
\text { homestay } \\
\text { in living } \\
\text { room }\end{array}$ & $\begin{array}{c}\mathrm{v} \\
\text { homestay } \\
\text { in living } \\
\text { room }\end{array}$ \\
\hline $\begin{array}{l}\text { Structure System } \\
\text { \& Method }\end{array}$ & $\begin{array}{c}v \\
\text { using nails } \\
\text { using } \\
\text { chiseld } \\
\text { stone for } \\
\text { foundation }\end{array}$ & $\begin{array}{c}\mathrm{v} \\
\text { using } \\
\text { nails }\end{array}$ & - \\
\hline Materials & $\begin{array}{c}\mathrm{v} \\
\text { wood } \\
\text { panels and } \\
\text { glass }\end{array}$ & $\begin{array}{c}\mathrm{v} \\
\text { wood } \\
\text { panels } \\
\text { and roof } \\
\text { tile }\end{array}$ & - \\
\hline
\end{tabular}

\section{REFERENCES}

[1] Hasan, Mubashar (2011). The Concept of Globalization and How This Impacted on Contemporary Muslim Understanding of Ummah. Journal of Globalization Studies. Volume 2, Number 2 / November 2011.

[2] Schiller, Herbert I. (1976). Communication and Cultural Domination. New York: International Arts and Sciences Press.

[3] Said, Edward W. (2003). Orientalism, New Edition. New york: Vintage Books, A Division of Random House.

[4] Sagrim, J. F. Hamah (2008). Benturan budaya lokal negara non kapitalisme dengan budaya global negara kapitalisme. Seminar nasional: Kebudayaan dan Keeksistensian Local Wisdom sebagai Tatanan Bangsa, Yogyakarta: UGM.

[5] Keraf, A. S. (2002). Etika Lingkungan. Jakarta: PT. Kompas.

[6] Desmond, Jane C. (1999). Staging Tourism: Bodies on Display from Waikiki to Sea World. University of Chicago Press.

[7] Suryawan, I Ngurah (2011). Teater Globalisme : Pariwisata, Interkoneksi Global, dan Nasib Manusia Bali di Garis Depan. Jurnal Kajian Bali Vol. 01, No. 01, April 2011. P. 152-181. 
[8] Theobald, William F. (Eds.) (2005). Global Tourism, 3rd Edition. Burlington: Elsevier Scienc

[9] Parma, I Putu Gede (2010). Kontribusi Pariwisata Alternatif Dalam Kaitannya Dengan Kearifan Lokal dan Keberlangsungan Lingkungan Alam. Jurnal Media Komunikasi FIS Universitas Pendidikan Ganesha. Edisi Khusus Perhotelan. Vol.9, No.2 September 2010. ISSN 1412-8683, P. $45-57$

[10] Sugiyono, (2013). Metode Penelitian Kuantitatif, Kualitatif dan $R \& D$. Bandung: Alfabeta.

[11] Suganda, Her (2006). Kampung Naga Mempertahankan Tradisi. Bandung: Kiblat Pustaka Utama.

[12] Kusnandar, L.O. et.al. (2013). Analisis Carrying Capacity Kawasan Berdasarkan Karakteristik Wisatawan, onasi Kawasan, Dan Daya Tampung Kawasan Sebagai Dasar Pengelolaan Pengunjung Di Kampung Naga Kabupaten Tasikmalaya. Antologi Manajemen Resort \& Leisure. Volume 1, No. 1, April 2013.

[13] Utami, Ardi, Wildan, Saputro, Utari (2014), Kajian Sustainable Material Bambu, Batu, ljuk dan Kayu pada Bangunan Rumah Adat Kampung Naga, Jurnal Reka Karsa Vol. 2 No. 2, August 2014, Bandung: ITENAS.e Inc.

[14] Wahyudi, A. and Pratiwi, C. W. (2011). Eksistensi Bangunan Tradidional Sunda Sebagai Pendekatan Kearifan Lokal, Ramah Lingkungan dan Hemat Energi. Prosiding Seminar Nasional The Local Tripod. Malang: Universitas Brawijaya.

[15] Somaatmadja, A. S. (2003). Studi adaptasi masyarakat tradisional dengan lingkungan hidupnya (faktor-faktor yang mempengaruhi pola perencanaan pelestarian lingkungan permukiman tradisional Kampung Naga di Tasikmalaya, Jawa Barat). Master-Thesis. Depok: UI.

[16] Arjuna. (2014). Arsitektur Rumah Adat Nusantara Nyaris Punah. Ranah Berita. [accessed: 7 October 2014 ]. http://ranahberita.com

[17] Wibowo, A. S. (2012). Arsitektur Vernakular Dalam Perubahan: Kajian Terhadap Arsitektur kampung Naga, Jawa
Barat. Proceeding Temu Ilmiah IPLBI. Bandung: IPLBI.

[18] FISE UNY. (2011). Handout PKL III, Program Studi Deografi, UNY.

[19] Yossihara. (2006). Kalau Orang Baduy Tolak Obyek Wisata, Kompas.

[20] Yossihara. (2010). Tips Wisata ke Baduy, Kompas.

[21] Prihantoro, Feri. (2006). Kehidupan Berkelanjutan Masyarakat Suku Baduy. AGEPP.

[22] Jamaludin, Permadi and Kharisma. (2013). Tinjauan Arsitektur Interior Tradisional Desa Kanekes. Jurnal Rekajiva Vol. 1 No. 2, January 2013, Bandung: ITENAS. 
